\title{
ФІТОСАНІТАРНІ РИЗИКИ ПОШИРЕННЯ ТА РОЗМНОЖЕННЯ КАРАНТИННИХ БУР'ЯНІВ, КОНТРОЛЬ ЇХ ЧИСЕЛЬНОСТІ В УМОВАХ СУМСЬКОЇ ОБЛАСТІ УКРАЇНИ
}

\author{
Бурдуланюк Алла Олександрівна \\ кандидат сільськогосподарських наук, доцент \\ Сумський національний аграрний університет, м. Суми, Україна \\ ORCID: 0000-0002-9258-745 \\ Burdalla@ukr.net
}

Татаринова Валентина Іванівна

кандидат сільськогосподарських наук, доцент

Сумський національний аграрний університет, м. Суми, Україна

ORCID: 0000-0001-5008-2276

TatarinovaSNAU@gmail.com

Рожкова Тетяна Олександрівна

кандидат біологічних наук, доцент

Сумський національний аграрний університет, м. Суми, Україна

ORCID: 0000-0002-0791-9736

Rozhkova8@gmail.com

Ємець Олександр Михайлович

кандидат біологічних наук, доцент

Сумський національний аграрний університет, м. Суми, Україна

ORCID: 0000-0003-1228-1439

Yemets_A@ukr.net

Деменко Віктор Михайлович

кандидат сільськогосподарських наук, доцент

Сумський національний аграрний університет, м. Суми, Україна

ORCID: 0000-0002-8264-2802

Vicmix64@ukr.net

Проаналізовано забур'яненість земель різного призначення Сумської області України карантинними бур'янами: амброзією полинолистою та повитицею польовою. Дослідження проводили у 2018-2020рр. в умовах Сумської області, яка територіально входить до складу північно-східної частини лівобережного Лісостепу України. Методика досліджень була загальноприйнятою.

У списку карантинних організмів, обмежено поширених в Україні (A-2), на території нашої країни поширені 5 видів комах, 5 збудників хвороб, 1 вид нематод та 6 видів бур'янів. На території Сумської області поширені: американський білий метелик (АБМ), золотиста картопляна нематода, амброзія полинолиста та повитиця польова. Станом на 2020 р. американський білий метелик поширений у 6 районах області: Великописарівському, Конотопському, Охтирському, Роменському, Тростянецькому та Сумському на площі відповідно 10,0; 40,0; 5,0; 167,0; 11,2 та 5,6 га. Загальна площа ураження склала 238,81 га. Золотиста картопляна нематода виявлена у 4 районах області на площі 569,95 га: Охтирський (17,19 га), Середино-Будський (140,43 га), Сумський (335,21 га) та Ямпільський (77,12 га). Амброзія полинолиста виявлена у 18 районах області (Білопільський, Буринський, Великописарівський, Глухівський, Конотопський, Краснопільський, Кролевецький, Лебединський, Липоводолинський, Недригайлівський, Охтирський, Путивльський, Роменський, Середино-Будський, Сумський, Тростянецький, Шосткинський, Ямпільський), у 209 населених пунктах, на площі 1834,3 га. Найбільша площа зараження спостерігається у Буринському, Великописарівському, Конотопському, Краснопільському районах та м. Суми: відповідно 200,7; 188,9; 237,5; 371,7 та 100,0 га. У більшості районів заражені землі несільськогосподарського призначення, винятком є лише Буринський, Конотопський, Краснопільський та Липоводолинський райони. Приватні присадибні ділянки громадян виявилися вільними від амброзії. Повитицю польову виявлено у Великописарівському районі на площі 1 га.

Ключові слова: амброзія полинолиста, повитиия польова, карантинний стан, карантинні організми, поширення.

DOI: https://doi.org/10.32845/agrobio.2021.1.1

В останні 7 років покращилися торгівельні зв'язки між Україною та Євросоюзом у результаті підписання угоди про євроінтеграцію. Економічна частина угоди була підписана 27 червня 2014 р. в ході засідання Ради ЄС Президентом

України та керівництвом Європейського Союзу і главами держав та урядів 28 держав - членів ЄС. Угодою передбачена поглиблена та всеохоплююча зона вільної торгівлі між Україною та ЄС. Угода визначає правову базу для вільного переміщення товарів, послуг, капіталів, частково робочої 
сили між Україною та ЄС, а також регуляторного наближення, спрямованого на поступове входження економіки України до спільного ринку ЄC (https://is.gd/rWwL9J).

Разом із позитивними з економічної та політичної точок зору наслідками, ця угода є небезпечною з фітосанітарної точки зору, оскільки поглиблюється проблема проникнення та розповсюдження на території нашої держави карантинних та інших небезпечних шкідливих організмів. А для будь-якої держави фітосанітарна безпека $є$ важливою, тому що карантинні та інші небезпечні шкідливі організми становлять реальну загрозу і за досить короткий термін можуть завдавати значних економічних збитків. Внаслідок діяльності шкідливих організмів сільгоспвиробники України втрачають щорічно понад $30 \%$ валових зборів урожаю. Особливо це стосується організмів, які потрапляють в Україну з імпортними вантажами і відносно яких не встановлено карантинного статусу, а також не визначено шкодочинність для рослинних ресурсів України (Stankevych, 2017). Це потребує оцінки небезпеки чужинних видів шкідливих організмів як для окремих територій, так і усієї площі нашої країни, їх економічного та сільськогосподарського значення. Саме тому дослідження у цьому напрямі $€$ актуальними.

Фітосанітарний порядок в Україні забезпечує Департамент фітосанітарної безпеки, контролю у сфері насінництва та розсадництва Державної служби з питань безпечності харчових продуктів та захисту споживачів (Держпродспоживслужба) України. Метою діяльності цієї служби є охорона території України від проникнення та розповсюдження карантинних об'єктів, запобігання отриманню шкоди від їх життєдіяльності (http://www.consumer.gov.ua).

На території Сумської області поширені такі карантинні шкідливі організми: американський білий метелик (Нyphantria cunea Drury), золотиста картопляна нематода (Globodera rostochiensis Wollenweber), амброзія полинолиста (Ambrosia artemisiifolia L.), повитиця польова (Cuscuta campestris Yunck.). Станом на 2020 р. американський білий метелик поширений у 6 районах області: Великописарівському, Конотопському, Охтирському, Роменському, Тростянецькому та Сумському на площі відповідно 10,0; 40,0; 5,0; 167,$0 ; 11,21$ та 5,6 га. Загальна площа ураження склала 238,81 га. Золотиста картопляна нематода виявлена у 4 районах області на площі 569,95 га: Охтирський (17,19 га), Середино-Будський (140,43 га), Сумський (335,21 га) та Ямпільський $(77,12$ га).

Амброзія полинолиста і повитиця польова належать до адвентивних видів рослин (від лат. adventicius - зайшлий, зовнішній), поява яких у певній місцевості пов'язана не з природним флорогенезом, а здебільшого з несвідомим занесенням їх людиною з первинного ареалу в інші флористичні області або на інші континенти у процесі господарської діяльності. У фолорі України налічують понад 700 адвентивних видів рослин (Borzykh, 2014).

За останні 50 років на нашій планеті відбувся демографрічний вибух. За даними ООН чисельність населення Землі у 2019 році склала 7,7 млрд осіб, а до кінця 2050 року досягне 9,7 млрд. Заступник Генсека ООН Аміна Мохаммед зазначила, що нинішні демографічні тенденції призводять до серйозних екологічних, економічних і соціальних проблем. Загострюється проблема співіснування людини із природою, відчувається нестача питної води, продуктів харчування, чи- стого повітря та енергоносіїв (https://is.gd/khlEbq.) Цю проблему можливо вирішити за рахунок інтенсифікації технологій вирощування сільськогосподарських культур. Важливим її елементом є захист рослин від шкідливих (у тому числі і карантинних) рослин (Pylypenko, 2016). Карантинні рослини - це особливо шкідливі адвентивні види, яких немає на території країни, або вони наявні обмежено і чисельність яких регулюється спеціальними заходами. 3 цієї точки зору найбільший ризик для України представляє продукція, що надходить з Туреччини. В продукції, що надходить із Молдови, виявляють значну кількість насіння карантинних бур'янів, порівняно з іншими країнами (Burdulaniuk et al., 2018).

Повитиця польова - однорічна рослина-паразит, яка має надзвичайно високу шкодочинність. Вона знижує врожайність сільськогосподарських культур і якість одержуваного врожаю, засмічує насіннєвий матеріал, погіршує якість кормів, що негативно впливає на здоров'я тварин. Крім того, повитиця $€$ переносником збудників ряду вірусних захворювань рослин. Проростки паразиту мають вигляд жовтуватих ниточок, які в міру виходу на поверхню поступово подовжуються і спіралеподібно обертаються до тих пір, поки не торкнуться до рослини-господаря і почнуть вести паразитичний спосіб життя. Одна рослина утворює більше 100 тис. насінин, яке здатне проростати і на світлі, і у темряві, зберігати схожість до 6 років. Оптимальна температура для проростання від +18 до $+30^{\circ} \mathrm{C}$. Повитиця квітує у липні-серпні. Проводять боротьбу з нею, видаляючи разом з рослиною-господарем до цвітіння, тобто до утворення насіння і спалюють. Якщо її просто подрібнити, то шматки розносяться вітром і кожен присмоктується до нової рослини, так повитиця може розселитися по всій ділянці. Плоди дозрівають у серпні-вересні (Kosolap, 2004).

у боротьбі з повитицею польовою велике значення мають профілактичні заходи. Посів проводять очищеними насінням. Очищення орного горизонту здійснюють шляхом загортання насіння бур'яну на велику глибину або стимулюють його проростання з наступним знищенням сходів поверхневою обробкою. На заражених полях із сівозміни виключають уражувані культури на 5-6 років (http://fitolab.kr.ua).

Амброзія полинолиста - дуже небезпечний карантинний бур'ян, який зустрічається на пустирях, у дворах будинків, на дачах і у містах, уздовж автомобільних і залізничних доріг, по берегах водоймищ, біля звалищ. Свою назву рослина отримала від пахучої мазі, якою грецькі боги натирали своє тіло. За зовнішніми ознаками амброзія полинолиста нагадує полин звичайний (Artemisia vulgaris L.). На цю схожість вказує видова назва - полинолиста (http://surl.li/mjrv). Бур'ян дуже шкодочинний, на забур'янених полях зниження врожаю сягає 50 \%. Рослина має потужну кореневу систему до 4 метрів, утворює велику надземну біомасу й затіняє польові культури. Амброзія полинолиста створює високу конкуренцію польовим культурам за споживанням поживних речовин і води. На утворення 1 т сухої речовини рослина споживає із ґрунту близько 950 т води, 24-33 кг азоту, 5-8 кг фосфору, 32 кг калію. Амброзія полинолиста, за відсутності стримуючих факторів (хвороб та шкідників), швидко розповсюджується, перемагаючи у конкуренції 3 місцевими видами, захоплює нові території (List \& Isles, 2015). Внаслідок надмірного висушування та виснаження 
ґрунту урожайність польових культур суцільного посіву знижується на 25-40 \%, а просапних на 40-60 \% і більше (Neilyk, 2008).

Пилок амброзії є одним із найагресивніших алергенів, здатним поряд з алергічною реакцією, викликати астму. У людей опухають слизові оболонки верхніх дихальних шляхів та очей, з'являється нежить і сльозотеча, чхання, підвищення температури, розвивається астма. При цьому не обов'язково, щоб рослина росла десь поряд 3 житлом людини, так як пилок може переміщуватися на значні відстані 3 допомогою вітру. Ніяка інша рослина не здатна так впливати на людину (Agnew et al., 2018). Для боротьби 3 A. artemisiifolia здійснюють обстеження земель: сільськогосподарських угідь, узбіч та схилів доріг, територій станцій, пунктів ввезення, приймання, зберігання та використання засміченого матеріалу, прилеглих до них територій (у радіусі 3 км). При виявленні, бур'ян потрібно скошувати не менше 3-4 разів за літо. На великих площах слід застосовувати гербіциди (http://surl.li/mjrv).

Метою досліджень було встановити поширеність карантинних бур'янів на землях сільськогосподарського та іншого призначення Сумської області, рекомендувати ефективну систему заходів попередження їх проникнення та розповсюдження.

Матеріали і методи досліджень. Дослідження проводились упродовж 2018-2020 рр. в умовах Сумської області, що територіально входить до північно-східної частини лівобережного Лісостепу України. Ця територія характеризується помірним, континентальним кліматом з помірною холодною зимою з відлигами і теплим літом. Найбільш холодними місяцями (за багаторічними середніми даними) є січень та лютий, теплими - липень і серпень. Абсолютний мінімум температур повітря спостерігається у січні, максимум - у серпні. Середньорічна (середньодобова) температура повітря впродовж 2018-2020 рр. коливалась від + 7,9 до + 9,7 ${ }^{\circ} \mathrm{C}$, тривалість безморозного періоду у межах 230-235 днів. 3а середнім багаторічним показником у регіоні випадає 597600 мм опадів, при цьому більша частина припадає на період квітень-жовтень. Загалом, потрібно відмітити перевищення температур до середнього багаторічного показника, кількість опадів не відрізнялась від середньостатистичних показників.

Методика досліджень була загальноприйнятою (Yeshchenko et al., 2005). Для своєчасного виявлення вогнищ бур'яну проводяться обстеження земельних угідь: узбіч та схилів основних автомобільних і залізничних магістралей, територій станцій, по яких перевозиться сільськогосподарська продукція; пунктів ввезення, приймання, зберігання та використання засміченого матеріалу, а також прилеглих до них територій; сільськогосподарських угідь. Використовували окомірний спосіб обліку забур'яненості амброзією полинолистою та повитицею польовою. Окомірний метод обліку бур'янів полягає в тому, що поле проходять по діагоналі і через рівні проміжки реєструють бур'яни. Дані спостережень оцінюють за чотирибальною шкалою, де 1 бал - бур'яни у фітоценозі поодинокі, а 4 бали - рослин більше ніж інших рослин, і вони їх пригнічують.

Результати. У списку карантинних організмів, обмежено поширених в Україні (А-2), на території нашої держави поширені 5 видів комах, 5 збудників хвороб, 1 вид нематод, 6 видів бур'янів. У список регульованих некарантинних шкідливих організмів (Б-3) занесено 3 види комах, 5 - хвороб, 2 - нематоди, 1 вид бур'янів (http://surl.li/ttid.). На території Сумської області поширені такі карантинні організми сільськогосподарських культур: американський білий метелик (АБМ), золотиста картопляна нематода, амброзія полинолиста, повитиця польова.

Батьківщиною амброзії полинолистої є Північна Америка. В Україні цей бур'ян уперше виявлено у 1914 році в с. Кудашівка Дніпропетровської області. Після 50-х років XX cт. амброзія почала активно «крокувати» у північному і західному напрямках України. Вперше у Сумській області амброзію полинолисту було виявлено в 1972 році на полях поблизу с. Самотоївка Краснопільського району (https://is.gd/foAqmv). Засмічує всі польові культури (особливо просапні й ярі зернові), овочеві, плодові, виноград, пасовища. При експорті зернових та олійних культур країни-імпортери вимагають відсутність у вантажі насіння амброзії полинолистої. А це додаткові витрати на очищення зерна від насіння амброзії для сільськогосподарських виробників (https://is.gd/D1SJhH.) Розвиваючи потужну надземну масу й кореневу систему, амброзія сильно пригнічує культурні рослини та виносить з ґрунту значну кількість поживних речовин. Крім конкуренції за елементи живлення й вологу, амброзія впливає алелопатично активними речовинами як на проростання насіння, так і на ріст культурних рослин. При сильному засміченні посівів амброзією полинолистою врожайність культур значно знижується. Крім цього, при збиранні врожаю засмічених посівів пізньостиглих культур (коноплі, соняшник, люцерна, насінники овочевих), у нього потрапляє насіння амброзії, яке досить важко відокремити. В таких випадках необхідні додаткові фінансові витрати на очищення насіннєвого матеріалу. При засміченні посівів багаторічних і однорічних трав на зелений корм, а також луків і пасовищ, якість корму знижується. У рослинах амброзії утворюється 0,07-0,15\% (відносно сирої маси) гірких речовин і ефірних масел. При згодовуванні корму з амброзією коровам смак молока стає гірким (http://surl.li/mjrv.).

Амброзію полинолисту можна назвати екологічно небезпечним бур'яном. Добре відомо, що пилок амброзії викликає у людей захворювання - амброзійний поліноз. У період цвітіння амброзії від цього захворювання страждає величезна кількість населення. У людей знижується працездатність, опухають слизові оболонки верхніх дихальних шляхів та очі, з'являється нежить і сльозотеча, розвивається астма. Від материнської рослини насіння може переноситися на значні відстані з водними потоками (талими водами навесні, по струмках, ярах, річках). Насіння довго тримається на поверхні води, тому що в ньому є повітряний мішок (між сім'янкою й оплоднем), i, крім того, поверхня оплодня має гідрофобні властивості й довго не розмокає (до 2 годин). Розповсюдженню бур'яну сприяють: вітер (у зимовий період, коли з нескошених рослин облітає насіння й сповзає по сніговому покриву); птахи, для яких насіння амброзії є кормом; транспорт (колеса тракторів, автомашин й інших транспортних засобів); взуття людей, до якого насіння прилипає разом із ґрунтом. Насіння $A$. artemisiifolia може потрапити у регіони, вільні від цього бур'яну, 3 вітчизняним та імпортним насіннєвим і продовольчим зерном, продуктами переробки зерна (соєвий шрот, комбікорми та ін.), відходами від пере- 
робки насіння сільськогосподарських культур (макуха соняшникова, відходи насіння люцерни або конюшини та ін.), із силосом, сіном, соломою, з підстилкою у вантажних автомобілях, з розсадою й іншими матеріалами (Neilyk, 2008).

Станом на 2020 рік $A$. artemisiifólia виявлена у 18 районах Сумської області, у 209 населених пунктах, на площі 1834,28 га. (табл. 1). Амброзія полинолиста виявлена у таких районах: Білопільський, Буринський, Великописарівський, Глухівський, Конотопський, Краснопільський, Кролевецький, Лебединський, Липоводолинський, Недригайлівський, Охтирський, Путивльський, Роменський, Середино-Будський,
Сумський, Тростянецький, Шосткинський та Ямпільський. Найбільша площа зараження спостерігається в Буринському, Великописарівському, Конотопському, Краснопільському районах, м. Суми: відповідно 200,70; 188,95; 237,46, 371,70 і 100,03 га. В переважній більшості районів заражено землі не сільськогосподарського призначення. Виключенням є лише Буринський, Конотопський, Краснопільський та Липоводолинський райони. Приватні присадибні ділянки громадян виявилися вільними від амброзії.

Зараженість земель Сумської області $A$. artemisifolia

\begin{tabular}{|c|c|c|c|c|c|c|c|c|c|}
\hline \multirow[b]{2}{*}{ № } & \multirow[b]{2}{*}{$\begin{array}{l}\text { Найменування } \\
\text { районів, міст }\end{array}$} & \multicolumn{3}{|c|}{ Заражено, шт. } & \multicolumn{4}{|c|}{ Площа зараження, га } & \multirow[b]{2}{*}{$\begin{array}{c}\text { кількість } \\
\text { карантинних } \\
\text { зон }\end{array}$} \\
\hline & & $\begin{array}{c}\text { населених } \\
\text { пунктів }\end{array}$ & $\begin{array}{c}\text { присадибних } \\
\text { ділянок }\end{array}$ & $\begin{array}{c}\text { господарств } \\
\text { всіх форм } \\
\text { власності }\end{array}$ & $\begin{array}{c}\text { на присадиб- } \\
\text { них } \\
\text { ділянках }\end{array}$ & $\begin{array}{c}\text { в господар- } \\
\text { ствах усіх } \\
\text { форм влас- } \\
\text { ності }\end{array}$ & $\begin{array}{c}\text { на інших зем- } \\
\text { лях }\end{array}$ & всього & \\
\hline 1 & Білопільський & 15 & 0 & 0 & 0,00 & 0,00 & 54,00 & 54,00 & 17 \\
\hline 2 & Буринський & 5 & 0 & 1 & 0,00 & 182,00 & 18,70 & 200,70 & 6 \\
\hline 3 & Великописарівський & 33 & 0 & 0 & 0,00 & 0,00 & 188,95 & 188,95 & 34 \\
\hline 4 & Глухівський & 6 & 0 & 0 & 0,00 & 0,00 & 9,55 & 9,55 & 6 \\
\hline 5 & Конотопський & 12 & 0 & 1 & 0,00 & 78,60 & 158,85 & 237,45 & 14 \\
\hline 6 & Краснопільський & 22 & 0 & 2 & 0,00 & 278,50 & 93,20 & 371,70 & 22 \\
\hline 7 & Кролевецький & 5 & 0 & 0 & 0,00 & 0,00 & 15,50 & 15,50 & 5 \\
\hline 8 & Лебединський & 20 & 0 & 0 & 0,00 & 0,00 & 50,90 & 50,90 & 20 \\
\hline 9 & Липоводолинський & 11 & 0 & 0 & 0,00 & 18,00 & 26,70 & 46,00 & 11 \\
\hline 10 & Недригайлівський & 6 & 0 & 0 & 0,00 & 0,00 & 36,50 & 36,50 & 6 \\
\hline 11 & Охтирський & 19 & 0 & 0 & 0,00 & 0,00 & 139,00 & 139,00 & 20 \\
\hline 12 & Путивльський & 1 & 0 & 0 & 0,00 & 0,00 & 1,50 & 1,50 & 1 \\
\hline 13 & Роменський & 6 & 0 & 0 & 0,00 & 0,00 & 43,15 & 43,15 & 6 \\
\hline 14 & Середино-Будський & 2 & 0 & 0 & 0,00 & 0,00 & 4,40 & 4,40 & 3 \\
\hline 15 & Сумський & 15 & 0 & 0 & 0,00 & 0,00 & 86,70 & 86,70 & 16 \\
\hline 16 & Тростянецький & 20 & 0 & 0 & 0,00 & 0,00 & 76,70 & 76,70 & 22 \\
\hline 17 & Шосткинський & 1 & 0 & 0 & 0,00 & 0,00 & 57,80 & 57,80 & 3 \\
\hline 18 & Ямпільський & 1 & 0 & 0 & 0,00 & 0,00 & 6,50 & 6,50 & 1 \\
\hline 1. & м. Глухів & 1 & 0 & 0 & 0,00 & 0,00 & 2,10 & 2,10 & 1 \\
\hline 2. & м. Конотоп & 1 & 0 & 0 & 0,00 & 0,00 & 50,61 & 50,61 & 1 \\
\hline 3. & м. Лебедин & 1 & 0 & 0 & 0,00 & 0,00 & 11,90 & 11,90 & 1 \\
\hline 4. & м. Охтирка & 1 & 0 & 0 & 0,00 & 0,00 & 25,70 & 25,70 & 1 \\
\hline 5. & м. Ромни & 1 & 0 & 0 & 0,00 & 0,00 & 11,34 & 11,34 & 1 \\
\hline 6. & м. Суми & 1 & 0 & 0 & 0,00 & 0,00 & 100,03 & 100,03 & 1 \\
\hline 7. & м. Шостка & 1 & 0 & 0 & 0,00 & 0,00 & 5,60 & 5,60 & 1 \\
\hline & Всього: & 209 & 0 & 5 & 0,00 & 557,10 & 1275,89 & 1834,30 & 220 \\
\hline
\end{tabular}

Повитиця польова (C. campestris Yunck.) є об'єктом внутрішнього карантину Сумської області. Станом на 2020 p. цей бур'ян виявлено у Великописарівському районі на площі 1 га (http://surl.li/mjrh). Повитиця польова - карантинний бур'ян, що живиться за рахунок рослини-господаря, на якій паразитує. Рослина не має ні коренів, ні листків. Найчастіше страждають від них польові культури: люцерна, льон, вика, буряк, морква, картопля, цибуля, тощо. Уражені рослини спочатку слабнуть, а потім призупиняють ріст і розвиток, поступово гинуть. Крім того, повитиці $€$ переносниками вірусних хвороб (Borzykh, 2014). Паразитичні рослини роду Cuscuta або взагалі не мають хлорофрілу, або містять його лише у невеликій кількості і зазвичай не мають фотосинтетичної активності. Тільки кілька видів Cuscuta все ще демонструють залишковий фотосинтез (García et al., 2014; Hibberd et al., 1998).

Обговорення. В сільському господарстві найбільш важливі види повитиці C. species, C. campestris та
C. pentagona., які поширені майже по всьому світу і мають широкий спектр господарів. С. campestris паразитує на багатьох різних рослинах з Brassicaceae, Leguminosae, Solanaceae та інших таксонів, негативно впливаючи на ріст і врожайність заражених господарів, а також значно впливає на структуру і функції рослинних угруповань, заражених цими паразитами. Повитиця може завдати значної шкоди молодим багаторічним бобовим культурам (люцерна або конюшина). Збиток, нанесений цим культурам, складається в основному у зниженні врожайності свіжої біомаси, яка може перевищувати $50 \%$, і значному зниженні виробництва насіння люцерни (Press et al., 1999).

При вивченні впливу повитиці польової на фізіологічні та анатомічні зміни у необробленому гербіцидами цукровому буряку (Saric-Krsmanovic et al., 2017) було встановлено зменшення товщини губчатих тканин, що прямо вплинуло на товщину мезофілу листя у рослин, заражених C. campestris. У дослідженнях, проведених у Канаді, було встановлено, що у 
заражених цукрових буряків повитиця значно зменшила площу провідних тканин, а також гідравлічну провідність черешка, порівняно 3 незараженими рослинами. Повитиця викликала значне зниження вмісту пігментів у заражених рослинах люцерни (15-68 \%) і цукрових буряків (1-54 \%). Результати, отримані в цьому дослідженні, підтвердили, що ця рослина-паразит впливає на більшість анатомічних параметрів стебла і листя люцерни, а також листка і черешка цукрових буряків. Також було виявлено, що повитиця збільшує вміст $\mathrm{N}, \mathrm{P}_{2} \mathrm{O}_{5}, \mathrm{~K}_{2} \mathrm{O}$ й органічні поживні речовини у заражених рослинах люцерни, в той час як заражені рослини цукрових буряків мали більш високий вміст азоту та органічних поживних речовин, порівняно з незараженими рослинами (Saric-Krsmanovic et al., 2019).

Дослідженнями, проведеними у 2014 році у степовій зоні України (Borzykh, 2012), встановлено, що через зміни погодних умов та технологій вирощування більшості сільськогосподарських культур такі бур'яни, як амброзія полинолиста, гірчак рожевий та повитиця польова займають значні території. У більшості південних областей ці бур'яни ростуть не лише вздовж автошляхів, залізничних колій, зерносховищ, складів, але і часто їх виявляють у посівах, де вони забруднюють урожай і ускладнюють його збирання, що суттєво позначається на якості одержаної продукції.

На острові Зміїний (Чорне море, Україна) у 20032010 рр. був проведений флоро-генетичний аналіз фітобіоти. Було виявлено 197 видів рослин із 139 родів та 46 родин, що належать до 3 класів та 2 відділів. Одним із видів була повитиця польова, яка була занесена на острів туристами, фахівцями і будівельниками (Vasylieva et al., 2019).

У дослідженні, проведеному у Румунії, встановлено, що A. artemisiifólia завдає великої шкоди і є реальною основною загрозою для агробіорізноманіття. Через цю рослину відбуваються величезні втрати у сільському та лісовому господарствах країни (Niculescu et al., 2019).

Амброзія полинолиста була одним із головних засмічувачів посівів соняшнику в умовах Приазов'я. При проведенні дослідження було встановлено, що при засміченні посівів соняшнику амброзією на перших етапах розвитку культури, слід очікувати суттєвого зниження урожайності. Чим доросліша культурна рослина, тим менше чутливою вона стає до засміченості бур'янами. В дослідженні для боротьби з бур'янами використовували гербіциди класу сульфонілсечовини (Hrynko \& Taradyn, 2018). На чорноземах центрального Передкавказзя, на основі комплексної оцінки агрофрізичних й агробіологічних факторів родючості, проведені дослідження по визначенню оптимальних умов обробітку ґрунту під соняшник. Було встановлено, що оранка знижує засміченість бур'янами, у тому числі і амброзією полинолистою. Зменшення глибини оранки, чи використання дискування не сприяє зменшенню засміченості посівів соняшнику бур'янами. Також було встановлено, що амброзія полинолиста мала алелопатичний вплив на проростання насіння редиски та соняшнику. Водна витяжка 3 наземних органів A. artemisiifolia у співвідношенні $(5: 50)$ мала сильний негативний вплив на проростання насіння соняшнику, коли проросло не більше $30 \%$ насіння (Kasmynyn, 2004).

Разом із негативним ставленням до амброзії полинолистої як до шкодочинної рослини, деякі дослідники зазначали лікарські властивості рослини. В дослідженнях, прове- дених в умовах Національного фармацевтичного університету, вивчали елементний склад амброзії. В ході дослідження елементного складу трави, листя, стебел, плодів та коренів амброзії полинолистої було виявлено не менше 19 елементів. В усіх досліджуваних видах сировини амброзії полинолистої переважали такі елементи, як калій, кальцій, силіцій, магній та фосффор. Установлено, що найбільший сумарний вміст елементів спостерігався в листі амброзії. Достатньо високий вміст макро- та мікроелементів дозволяє вважати амброзію полинолисту перспективним джерелом мінеральних елементів та пояснює її використання у народній медицині при різноманітних захворюваннях опорно- рухового апарату (Horiacha \& Zhuravel, 2014).

Висновки. A. artemisiifolia виявлена у 18 районах Сумської області (Білопільський, Буринський, Великописарівський, Глухівський, Конотопський, Краснопільський, Кролевецький, Лебединський, Липоводолинський, Недригайлівський, Охтирський, Путивльський, Роменський, Середино-Будський, Сумський, Тростянецький, Шосткинський, Ямпільський), в 209 населених пунктах, на площі 1834,28 га. Найбільша площа зараження спостерігається в Буринському, Великописарівському, Конотопському, Краснопільському районах, м. Суми і складає відповідно 200,70; 188,95; 237,46; 371,70 та 100,03 га. В переважній більшості районів заражено землі не сільськогосподарського призначення, виключенням є лише Буринський, Конотопський, Краснопільський та Липоводолинський райони. Приватні присадибні ділянки громадян виявилися вільними від амброзії.

Повитиця польова (C. campestris) є об'єктом внутрішнього карантину Сумської області. Цей бур'ян виявлено у Великописарівському районі на площі 1 га.

Так як $A$. artemisiifolia та C. campestris $€$ особливо небезпечними адвентивними видами бур'янів, це вимагає особливої уваги до заходів боротьби із ними. В умовах Сумської області пропонуємо дотримуватись інструкції з виявлення, локалізації та ліквідації вогнищ карантинних бур'янів (http://surl.li/vsks). Ця інструкція визначає порядок здійснення комплексу фітосанітарних заходів із виявлення, локалізації і ліквідації вогнищ карантинних бур'янів. Вона є обов'язковою для виконання юридичними та фізичними особами, які займаються вирощуванням, вивезенням, ввезенням, заготівлею, переробкою, зберіганням, перевезенням, реалізацією та використанням підкарантинних матеріалів і об'єктів. Інструкція встановлює: посилення карантинних заходів, спрямованих на недопущення потрапляння та поширення бур'янів у вільні від них райони із заражених районів. Важливо своєчасно проводити обстеження схилів доріг та узбіч, територій станцій, пунктів ввезення, приймання, зберігання та використання засміченого посівного матеріалу, прилеглих до них територій (в радіусі не менше 3 км), сільськогосподарських угідь. При виявленні карантинних бур'янів негайно проводити локалізацію та ліквідацію. Необхідно знищити рослини одразу після виявлення, оптимально ще до початку цвітіння та плодоношення, адже амброзія розмножується тільки насінням. Скошені рослини треба знищити: спалити або закопати, щоб пилок з них не продовжував поширюватись. При виявленні значних площ, заражених амброзією полинолистою, застосовувати гербіциди, дозволені до використання в Україні. Використовувати запобіжні заходи боротьби, до яких відносять очищення посівного матеріалу від насіння бур'янів. 3 агротех- 
нічних методів боротьби використовувати правильне чергування культур у сівозміні. Проводити обробку ґрунту та догляд за посівами, спрямовані на зниження запасів насіння даного виду бур'яну в ґрунті й запобігання повторного за- смічення як ґрунту, так і врожаю сільськогосподарських культур. На дуже засмічених амброзією землях, кращим заходом по очищенню ґрунту від запасів насіння $€$ використання чистого пару, де, за правильного обробітку, засміченість бур'яном знижується на 70-80 \%.

\section{Бібліографбічні посилання:}

1. Agnew, M., Banic, I., Lake, I. R., Goodess, C., Grossi, C. M., Jones, N. R., Plavec, D, Epstein, M., \& Turkalj, M. (2018). Modifiable Risk Factors for Common Ragweed (Ambrosia artemisiifolia) Allergy and Disease in Children: A Case-Control Study. International Journal of Environmental Research and Public Health, 15(7), 1339. doi: 10.3390/ijerph15071339.

2. Ahrarnyi cektor Ukrainy. Buriany. Ambroziia polynolycta. [Weeds. Ambrosia artemisiifolia]. [Electronic resource]. Access mode: http://surl.li/mjrv (in Ukrainian).

3. Borzykh, O. I. (2012). Fitocanitarna bezpeka Ukrainy [Phytosanitary safety of Ukraine]. Zakhyct i karantyn roclyn, 58, 3-8. (in Ukrainian). Ukrainian).

4. Borzykh, O. I. (2014). Karantynni buriany v Ukraini [Quarantine weeds in Ukraine]. Karantyn i zakhyst roslyn, 8, 11-14. (in

5. Burdulaniuk, A. O., Rozhkova, T. O., \& Tatarynova, V. I. (2018). Ocnovy karantynu roclyn [Basics of plant quarantine]. Navchalnyi posibnyk. SNAU, Sumy, 151 (in Ukrainian).

6. Den'. V OON nazvaly chyselnist naselennia Zemli [The OUN named the population of the Earth]. [Electronic resource]. Access mode: https://is.gd/khlEbq (in Ukrainian).

7. Derzhavna sluzhba Ukrainy z bezpechnocti kharchovykh produktiv ta zakhyctu spozhyvachiv [State Service of Ukraine for Food Safety and Consumer Protection]. [Electronic resource]. Access mode: http://www.consumer.gov.ua (in Ukrainian).

8. Derzhavna sluzhba Ukrainy z pytan bezpechnosti kharchovykh produktiv ta zakhystu spozhyvachiv. Derzhavna ustanova "Kirovohradska oblasna fitosanitarna laboratoriia" [State Service of Ukraine for Food Safety and Consumer Protection. Kirovohrad Regional Phytosanitary Laboratory State Institution]. [Electronic resource]. Access mode: http://fitolab.kr.ual (in Ukrainian).

9. Derzhavna sluzhba Ukrainy z pytan bezpechnosti kharchovykh produktiv ta zakhystu spozhyvachiv. Derzhavna ustanova "Ternopilska oblasna fitosanitarna laboratoriia". [State Service of Ukraine for Food Safety and Consumer Protection. Ternopil Regional Phytosanitary Laboratory State Institution Cuscuta campestris]. [Electronic resource]. Access mode: http:// http://surl.li/ttid (in Ukrainian).

10. Derzhavna ustanova «Sumcka oblasna fitosanitarna laboratoriia» [Sumy Regional Phytosanitary Laboratory]. [Electronic resource]. Access mode: http://surl.li/mjgy (in Ukrainian).

11. García, M. A., Costea, M., Kuzmina M. \& Stefanovic, S. (2014). Phylogeny, character evolution, and biogeography of Cuscuta (dodders; Convolvulaceae) inferred from coding plastid and nuclear sequences. Am. J., 101, 670-690. doi: $10.3732 / a j b .1300449$.

12. Hibberd, J. M., Bungard, R. A., Press, M. C., Jeschke, W. D., Scholes, J. D., \& Quick, W. P. (1998). Localization of photosynthetic metabolism in the parasitic angiosperm Cuscuta reflexa. Planta, 205, 506-513. doi: 10.1007/s004250050349.

13. Holovne upravlinnia Derzhprodspozhyvsluzhby v Sumskii oblasti. [The main department of the State Consumer Service in Sumy region]. Upravlinnia fitosanitarnoi bezpeky. [Electronic resource]. Access mode: http://surl.li/mirh (in Ukrainian).

14. Horiacha L. M., \& Zhuravel, I. O. (2014). Elementnyi sklad ambrozii polynolyctoi (Ambrosia artemisiifolia) [Elemental composition. (Ambrosia artemisiifolia)]. Ukrainckyi medychnyi almanakh, 17(1), 145-146 (in Ukrainian).

15. Hrynko A. V., \& Taradyn S. A. (2018) Ekonomycheskaia otsenka prymenenyia pochvennykh herbytsydov na podsolnechnyke [Economic evaluation of the use of soil herbicides on sunflower]. Ekonomyka y byznes: teoryia y praktyka, Nauchnyi zhurnal. [Electronic resource]. Access mode: http://surl.li/mmja (in Russian).

16. Infoindustriia. Vash putevodytel v myre ahroindustryy. Ambroziia polynolysta [Infoindustry. Your guide to the world of the agroindustry]. [Electronic resource]. Access mode: https://is.gd/D1SJhH (in Russian).

17. Kasmynyn, H. H. (2004). Effektivnost' osnovnoj obrabotki pochvy v upravlenii faktorami pochvennogo plodorodija pri vozdelyvanii podsolnechnika na chernozeme vyshhelachennom Central'nogo Predkavkaz'ja [The effectiveness of the maine tillage in the management of soil fertility factors in the cultivation of sun flower on leached black soil of the Central Ciscaucasia]. [Electronic resource]. Access mode: http://surl.li/mmfj (in Russian).

18. Kosolap, M. P. (2004). Herbolohiia [Herbology]. Navchalnyi posibnyk. Aristei, Kyiv, 367 (in Ukrainian).

19. List Vasc. PI., Isles, Br. (2015). Biological Flora of the British Isles. Ambrosia artemisifolia. Journal of Ecology, 103, 10691098,135, 74, 1 doi: 10.1111/1365-2745.12424

20. Neilyk, M. M. (2008). Herbolohichnyi monitorynh ahrotsenoziv ta osoblyvosti poshyrennia ambrozii polynolyctoi u Vinnytskii oblasti. Kormy i kormovyrobnytstvo [Herbological monitoring of agrocenoses and peculiarities of Ambrosia artemisiifolia L. distribution]. Mizhvidomchyi tematychnyi naukovyi zbirnyk, 60, 79-82 (in Ukrainian).

21. Niculescu, M., Fagaras, M. M., Olaru, L. A., \& Niculescu, L. (2016). The corology, egology and phytosociogy of the Ambrosia artemisiifólia L., invasive alien plantin the southwestern part of Romania. International Multidisciplinary Scientific Geo Conference: Sofia: Surveying Geology \& Mining Ecology Management (SGEM). Sofia, 3, 363-370. doi: 10.5593/SGEM2016/HB63/S08.047.

22. Press, M. C., Scholes, J. D., \& Watling, J. R. (1999). Parasitic plants: physiological and ecological interactions with their hosts. Physiological plant ecology. Blackwell Science, Oxford, UK, 175-197. doi: 10.1093/aob/mcn214. 
23. Pro zatverdzhennia Instruktsii z vyiavlennia, lokalizatsii ta likvidatsii vohnyshch karantynnykh burianiv [About the statement of the instruction on detection, localization and liquidation of the centers of quarantine weeds]. [Electronic resource]. Access mode: http://surl.li/vsks

24. Pylypenko, L. A. (2016). Analiz fitocanitarnoho ryzyku rehulovanykh shkidlyvykh orhanizmiv, vidsutnikh v Ukraini [Analysis of phytosanitary risk of regulated pests absent in Ukraine], Koloobih, Kyiv, 56 (in Ukrainian).

25. Samotoivka. Wikipedia. [Electronic resource]. Access mode: https://is.gd/foAqmv

26. Saric-Krsmanovic, M., Bozic, D., Radivojevic, L., \& Umiljendic, J. G. (2019). Vrbnicanin Response of alfalfa and sugar beet to field dodder (Cuscuta campestris Yunck.) parasitism: a physiological and anatomical approach. Canadian Journal of Plant Science, 99-209. doi.org/10.1139/CJPS-2018-0050.

27. Saric-Krsmanovic, M. M., Bozic, D. M., Radivojevic, L. M., Gajic Umiljendic, J. S., \& Vrbnicanin, S. P. (2017). Effect of Cuscuta campestris parasitism on the physiological and anatomical changes in untreated and herbicide-treated sugar beet. J. Environ. Sci. Health, Part B: Pestic., Food Contam., Agric. Wastes, 52, 812-816. doi: 10.1139/cjps-2018-0050.

28. Skálová, H. Guo WenYong, Wild, J. \& Pyšek, P. (2017). Ambrosia artemisiifolia in the Czech Republic: history of invasion, current distribution and prediction of future spread, Preslia, 89(1), 1-16. doi: 10.23855/preslia.2017.001

29. Stankevych, S. V. (2017). Metody ohliadu ta ekspertyzy pidkarantynnykh materialiv [Methods of inspection and examination of quarantine materials]. Navch. Posibnyk. FOP Brovin O.V., Kharkiv, 255 (in Ukrainian).

30. Uhoda pro asotsiatsiiu. Uriadovyi portal [Association Agreement. Government portal]. [Electronic resource]. Access mode: https://is.gd/rWwL9J (in Ukrainian).

31. Vasylieva, T. V., Kovalenko, S. H., \& Nemertsalov, V. V. (2017). Floro-henetychnyi analiz fitobioty ostrova Zmiinyi (Chorne more, Ukraina) [Floro-genetic analysis of Snake Island (Black Sea, Ukraine)]. Naukovi zapysky Ternopilskoho natsionalnoho pedahohichnoho universytetu imeni Volodymyra Hnatiuka. Seriia: Biolohiia, 2, 16-20 (in Ukrainian).

32. Yeshchenko, V. O., Kopytko, P. H., \& Kostohryz, P. V. (2005). Osnovy naukovykh doslidzhen v ahronomii: pidruch [Fundamentals of scientific research in agronomy]. Diia, Kyiv, 186 (in Ukrainian).

Burdulanyuk A. 0., PhD (Agricultural Sciences), Associate Professor, Sumy National Agrarian University, Sumy, Ukraine

Tatarynova V. I., PhD (Agricultural Sciences), Associate Professor, Sumy National Agrarian University, Sumy, Ukraine

Rozhkova T. O., PhD (Biological Sciences), Associate Professor, Sumy National Agrarian University, Sumy, Ukraine

Yemets O. M., PhD (Biological Sciences), Associate Professor, Sumy National Agrarian University, Sumy, Ukraine

Demenko V. M., PhD (Agricultural Sciences), Associate Professor, Sumy National Agrarian University, Sumy, Ukraine

PHYTOSANITARY RISK OF SPREAD AND REPRODUCTION OF QUARANTINE ORGANISMS, CONTROL OF THEIR NUMBER IN THE CONDITIONS OF THE SUMY REGION OF UKRAINE

The littering of lands of different purposes of Sumy region of Ukraine, with quarantine weeds of ragweed and field cover was analyzed. The research was conducted in 2018-2020 in the conditions of Sumy region, which is territorially part of the north-eastern part of the left-bank Forest-Steppe of Ukraine. Research methods are generally accepted.

In the list of quarantine organisms of limited distribution in Ukraine (A-2), 5 species of insects, 5 diseases, 1 nematode and 6 species of weeds are widespread in our country. Hyphantria cunea, Globodera rostochiensis, Ambrósia artemisiifolia, Cuscuta campestris Yuncker are widespread in the Sumy region. $\mathrm{H}$. cunea is distributed in 6 districts of the region: Velykopysarivsky, Konotop, Okhtyrsky, Romensky, Trostyanetsky and Sumy on the area of 10.0; 40.0; 5.0; 167.0; 11.2; 5.6 hectares, respectively. The total affected area was 238.81 hectares. G. rostochiensis was found in 4 districts of the region: Okhtyrsky (17.19), Seredino-Budsky (140.43), Sumy (335.21), Yampilsky (77.12), on an area of 569.95 hectares. A. artemisiifolia was found in 18 districts of the region: (Bilopilsky, Burynsky, Velykopysarivsky, Glukhivsky, Konotop, Krasnopilsky, Krolevets, Lebedynsky, Lipovodolinsky, Nedrygailivsky, Okhtyrsky, Putivlsky, Romensky, Seredino-Budsky, Sumy, Trostyanetsky, Shostkynsky, Yampilsky) settlements, on the area of 1834.3 hectares. The largest area of infection is observed in Buryn, Velykopysarivsky, Konotop, Krasnopil districts, Sumy: respectively 200.7; 188.9; 237.5; 371.7; 100.0 hectares. In most districts, non-agricultural lands are infected, with the exception of Buryn, Konotop and Krasnopil and Lipovodolinsky districts. Private homesteads of citizens were free of ragweed. C. campestris was found in Velykopysarivskyi district on the area of one hectares.

Key words: Ambrosia artemisiifolia, Cuscuta campestris Yuncker, quarantine condition, quarantine organisms, distribution hectares

Дата надходження до редакції: 22.02.2021 р. 